\title{
The Knowledge of Standard Precautions among Nurses in Public and Private Tertiary Care Hospital Lahore
}

\author{
Dilnasheen*, Afsar Ali, Naseem Rooman \\ National College of Nursing, The University of Lahore, Lahore, Pakistan.
}

\begin{abstract}
Background: Nurses and other healthcare workers are at risk of occupational hazards in the healthcare setting. Nurses are prone to expose with blood born infection like $\mathrm{HIV}, \mathrm{HCV}$ and $\mathrm{Hb}$ B. Proper implication of standard precaution effectively control the hospital acquired infection.
\end{abstract}

Aims: To assess the Knowledge of standard precaution among nurses working at private and public hospital.

Method: A cross sectional study was conducted among nurses in a tertiary care hospital at private and public sector. The duration of study was from February 2018 to May 2018. A self-structured questioner was used to obtain information from nurses. Data was analyzed using SPSS version 21 and the level of significance was at pvalue $<0.05$.

Results: Total respondent nurses were 201.Response rate rate was $98 \%$. The results shows $42.3 \%$ of the participants in this study had poor knowledge, $40.3 \%$ have average knowledge, and $17.4 \%$ have good knowledge about the standard precaution. Total female participants were 169 (mean knowledge score was 14.14) and male participant 32 (mean knowledge score was 16.13). The results show significant difference between female verses male participant were $(\mathrm{p}=0.03)$.

Total private hospital participants are 99 mean knowledge score was $13.45+3.863$ and public hospital nurses included 102 mean knowledge score is $14.66+3.167$ that is greater than private hospital. There is significant difference between public versus private hospital $(\mathrm{p}=0.17)$.

Conclusion: As the result indicate poor knowledge of standard precaution among nurses at private and public hospital. it is suggested to provide training sessions on infection control with hands on workshops. This is also suggested infection control topics should add in Nursing curriculum and PNC should take initiate post basic one year Diploma in Infection Control.

Keywords: Knowledge, Standard precaution, Infection control, Hospital acquired infection, Infection prevention, Nurse.

\section{INTRODUCTION}

Every hospital may have a challenge of increased number of Hospital acquired Infections, which is a major concern of health professionals. According to statistics of the WHO, a large number of (7.1 million cases) hospital acquired infections occur annually in the world. It is believed that the prevalence of HAI is among the 5\% people who get hospital infection. Almost 1 lake individuals die due to hospital acquired infections and it produce a huge amount of financial burden (around 32 million US dollars) on the shoulder of society [1].

The prevalence of hospital infection is found to be very high in the developing countries $(10.1 \%)$, as compare to the developed world (7.6\%), which means that the developing countries need more attention to overcome the [2]. A high number of nurses and doctors are at a greater risk of the most common hazard in the form of a serious threat of communicable diseases. Communicable diseases make the health professionals prone to serious effects. Hospital acquired infections occurs due to certain bacteria, viruses and

*Address correspondence to this author at the National College of Nursing, The University of Lahore, Lahore, Pakistan.

E-mail: dilnasheenrana@ymail.com fungi during treatment process at the hospital. Such infection at many times are devastating and life threatening [3].

'Universal Standard precautions', a set of some standard guidelines is applied for the protection of health care workers as well as patients to save them from potential infections caused by contact with infectious body substances like infected blood, and other infected body fluids such as feces and urine etc. [4].

Standard precautions are a combination of few very important protective measures. Some measures include, proper hand washing before and after contact with client, to use some personal protective measures and equipment, safe practices of using sharps and appropriate disposal of them, have clean environment on regular basis, taking care of reusable medical instruments, taking care of respiratory hygiene, applying aseptic non-touch technique, appropriate hospital waste management and effective care of Intravenous or other lines management. Many hospitals in the world have applied the standard precautions such as hand washing, use of personal protective equipment (gloves, face mask, eye wear and gown), patients safe placement and precautions during handling of laboratory specimens [5]. 
With the help of standard precautions, the exposure to so many infectious materials can be reduced. As a result there will be a very high reduction in the rate of hospital and occupational acquired infection. By precaution the known as well as unknown sources of causing hospital acquired infection will be controlled and will reduce the threat of HAI diseases among the patients and health professionals [6].

Standard precautions at health care systems are considered as protective measures for health care professionals, the patients and society at large. They are widely recognized as standards to reduce the hospital acquired infections among health care professionals as well as [7]. Moreover, the standard precautions following the principles of infection control such as effective hand washing, use of protective equipments and thus help the health care workers such as nurses and doctors to protect them from potentially infected materials of the patients such as their blood and other fluids [8].

Instead of so many available guidelines in the world, still the standard precaution are not well known and also not practiced by the health care professionals. The health professionals of developed and developing countries both are having insufficient knowledge regarding the universal standard precautions [9]. Following the required applicationof standard precautions can help the health care systems to protect their employees as well as their clients. In the countries like Nigeria and Africa the health care workers do not follow the universal standard precaution to the maximum level. They lack consistency and correction in the application of standard precaution and thus may lead to negative consequences [8].

It is essential need of Health care systems to assess the knowledge of nurses and doctors regarding the concepts of standard precautions at hospitals. It is believed that the knowledge of standard precautions have some effect on their implementations in the health care systems. Centre for disease control also recommends that application and adherence to standard precautions are very essential for health of the professionals and safety of the clients. In some countries like Brazilian Ministry of Health the adherence of standard precautions are used compulsory and the occupational exposure to Biological hospital waste Material which are Potentially Contaminated, is minimized [10].

Here knowledge refers to the remembering of information which is required for behavioral change. According to cognitive behavioral theory knowledge is interlinked with behavior change. It is believed that the knowledge is necessary to bring behavioral change in an individual which might not be sufficient at occasion to influence nurses and health care professionals behavior [11]. This portion consists of some literature review on nurses' knowledge of standard precaution.

A research study was conducted to assess the knowledge, attitude and practices among nursing students in Yemen. It was found that the knowledge level of nurses and nursing students was very low regarding standard precaution at clinical practices [12].

Another study findings reveals that majority of the study participants had sufficient knowledge level regarding infection, proper hand washing, use of gloves and procedure after needle stick or sharp injuries. On the other hand the knowledge was found low about gell application and use of disinfectants. The low level of knowledge was considered as the effect of work pressure, lack of time and lack of facilities [13].

Another study was conducted among 130 nurses about prevention of hospital infection. The findings of the study reveals that majority of the nurses had poor knowledge of infection prevention and control [14]. The results of another survey found that knowledge level was not up to standard and $43 \%$ nurses had poor level of knowledge about hospital infection. The knowledge level was found significantly different between males and females $(r=00.8 p=0.02)$ [15].

A study among nursing students showed some good level of knowledge, about $90 \%$ students have good level of knowledge about standard precautions at hospitals [6]. Another Nigerian study found that above $90 \%$ of the participants have good knowledge of standard precautions. The knowledge of safe injection was found low among the study participants. Among the junior nurses and other lower health care professionals the knowledge was found low as compare to the experienced people [16].

Findings of another study show that only $13 \%$ of the study participants had adequate knowledge of the standard precautions. Female nurses had better knowledge than males and 10 years or more experienced nurses also had better knowledge of standard precautions $(p<0.05)$. Compliance of using sterile gloves, effective use of needles and sharps was higher than the knowledge of these procedures recorded $(\mathrm{p}<$ 0.05) [17].

An important study conducted to assess the knowledge of nurses about standard precautions. A very good percentage $(86.3 \%)$ of the participants had awareness about standard precaution. More than $50 \%$ participants were aware of the personal protective equipment and the role of hand hygiene in the prevention of hospital acquired infection. About $80 \%$ of the participants every patient admitted at the hospital could be the source of infectious blood and body fluid [18].

Results of another study conducted among health professional showed that $80 \%$ of the research participants had good knowledge about standard precautions. It was also suggested that to improve knowledge and adherence towards standard precaution, there must be proper education and training [4]. 
In another study among health professionals knowledge of Standard precaution was good. According to this study the awareness of personal protective equipment was high among the participants. Poor standard precaution was considered to be caused by the unavailability of personal protective equipment such as gown, gloves etc. [5].

\section{Aims of the Study}

The purpose of this research is to bring awareness among nurses and other health care professionals about proper adherence of standard precautions. It will determine the knowledge of standard precautions among nurses in public tertiary care hospital Lahore Pakistan. Specific Objective was to determine the knowledge of standard precautions among nurses in public and private tertiary care hospital Lahore Pakistan

\section{Significance of the Study}

This study examines the knowledge of nurses regarding the use and adherence to standard precautions. The findings of this research study will be helpful for the health care systems and health policy makers, the higher hospital management and other stakeholders to construct policies and implement standard precaution among health care professionals. The findings will help the nurses and other health professionals to get a thorough understanding of effective use of standard precautions in their practices and make themselves healthy and their clients safe.

\section{METHODS}

\section{Research Design}

The knowledge of nurses regarding standard precaution was assessed with the help of a cross sectional descriptive survey. The information from the participants was collected at one point in time therefore, cross sectional design.

\section{Population}

Registered nurses of Children hospital and the National Hospital working at ICUs and other critical areas were recruited in the study.

\section{Time Period}

This study was carriod out from February 2018 to May 2018 for about 4 months period.

\section{Sampling}

Convenient sampling technique was used for the collection of data. This is non-probability sampling technique in which researcher selects subjects of his convenience and accessibility. A Sample of $n=200$ was recruited from both selected hospitals.

\section{Research Instrument}

Data was collected with the help of a Knowledge based questionnaire adapted from thesis named" Knowledge of nurses about standard precaution" [19]. Questionnaire consists of three sections. Part I focusing on demo-graphic data of participant. The second part consists of 10 knowledge based questions in the form of Yes, No and don't know. In the third part there are 17 knowledge based questions in the form of multiple choices with one correct answer.

\section{Data Gathering Procedure}

The questionnaire was distributed to the participants in printed form where they answered the entire question according to their own understanding. A time of about 30 minutes was given to fill the questionnaires. Then the filled questionnaires were collected.

\section{Methods Used to Analyze Data}

Data was analyzed by using SPSS version 21. Descriptive analysis was performed in the form of averages, and percentages through tables and graphs. The difference of knowledge among the nurses of public versus private hospital was analyzed with the help of independent $t$ test.

\section{Ethical Consideration}

First of all the permission was granted from the supervisor and the principal of the National college of Nursing Lahore. Then permission was taken from the head of the institution where the research will take place. Written permission in the form of informed consent was taken from each individual participant. The study was conducted in Children hospital and National Hospital by getting permission from head of department of the institute. No personal identity of participants was revealed. No participant was forced to take part in research work. All the confidential data must be treated with confidentiality.

\section{RESULTS}

\section{Profile of the Respondents}

Respondents were taken from different selected groups of National Hospital and Children Hospital Lahore.

Table 1. Demographic Findings.

\begin{tabular}{|c|c|c|}
\hline Variables & Number (n) & \% \\
\hline Age & 70 & \\
18 to 25 & 113 & $34.8 \%$ \\
26 to 35 years & 18 & $96.2 \%$ \\
Above 35 years & & \\
\hline Gender & 32 & $15.9 \%$ \\
Male & 169 & $84.1 \%$ \\
Female & &
\end{tabular}

Continued... 
Table 1. (Continued)

\begin{tabular}{|c|c|c|}
\hline Variables & Number (n) & \% \\
\hline Education & & \\
Nursing Diploma & 140 & $69.7 \%$ \\
Diploma/specialization & 60 & $29.5 \%$ \\
BSN/PRN BSN and above & 1 & $5 \%$ \\
\hline Place of work & & \\
Medical ward & 85 & $42.3 \%$ \\
Surgical ward & 60 & $29.9 \%$ \\
Adult ICU & 28 & $13.9 \%$ \\
Paeds/NICU & 28 & $13.9 \%$ \\
\hline Experience & & \\
Less than 5 years & 82 & $40.8 \%$ \\
6-10 years & 100 & $49.8 \%$ \\
Above 10 years & 19 & $9.5 \%$ \\
\hline
\end{tabular}

Table 1 shows that $34.8 \%$ of the participants were age $18-25$ years, $56.2 \%$ were age $26-35$ years and $9 \%$ participants were above 35 years. It also shows that $15.9 \%$ of the study participants were males while $84.1 \%$ participants were Females. Similarly 69.7\% participants were Nurses Diploma, $29.8 \%$ of the participants were Diploma plus specialization and $0.5 \%$ were BSN or above. Regarding experience of the study participants, $40.8 \%$ had experience less than 5 years, $49.7 \%$ were $6-10$ years of experience and $9.5 \%$ participants had experience greater than 10 years.

Table 2. Nurses' Knowledge of Hospital Acquired Infection and Standard Precaution.

\begin{tabular}{|c|c|c|c|c|c|c|c|}
\hline S. No. & Statement & & Tes & & No & Not & nown \\
\hline & & $\mathbf{N}$ & $\%$ & $\mathbf{N}$ & $\%$ & $\mathbf{N}$ & $\%$ \\
\hline 1. & $\begin{array}{l}\text { Hospital acquired infections are the result of self-infection, } \\
\text { cross-infection \&environmental infection }\end{array}$ & 178 & $88.56 \%$ & 16 & $7.96 \%$ & 7 & $3.48 \%$ \\
\hline 2. & $\begin{array}{l}\text { The single most important measure for preventing Hospital } \\
\text { Acquired Infections is hand hygiene. }\end{array}$ & 166 & $82.58 \%$ & 33 & $16.43 \%$ & 2 & $1.0 \%$ \\
\hline 3. & Immunization against Hepatitis B is a standard precaution. & 148 & $73.6 \%$ & 49 & $24.4 \%$ & 4 & $2.0 \%$ \\
\hline 4. & $\begin{array}{l}\text { Patients receiving immunosuppressive therapy are more susceptible } \\
\text { to Hospital Acquired Infections. }\end{array}$ & 143 & $71.1 \%$ & 54 & $26.9 \%$ & 4 & $2.0 \%$ \\
\hline 5. & $\begin{array}{l}\text { Sterilization is a process of killing of microorganism } \\
\text { including spores. }\end{array}$ & 125 & $62.18 \%$ & 72 & $35.8 \%$ & 4 & $2.0 \%$ \\
\hline 6. & $\begin{array}{l}\text { Hospital Acquired Infections (HAl) is synonymous } \\
\text { to nosocomial infections. }\end{array}$ & 131 & $65.2 \%$ & 61 & $30.3 \%$ & 9 & $4.5 \%$ \\
\hline 7. & $\begin{array}{l}\text { The most important factor involved in hand } \\
\text { washing is friction. }\end{array}$ & 147 & $73.1 \%$ & 43 & $21.4 \%$ & 11 & $5.5 \%$ \\
\hline 8. & $\begin{array}{l}\text { Following a procedure, hand washing is necessary } \\
\text { after removing gloves. }\end{array}$ & 141 & $70.1 \%$ & 53 & $26.4 \%$ & 7 & $3.5 \%$ \\
\hline 9. & Standard precautions apply only to all body fluids. & 119 & $59.2 \%$ & 73 & $36.3 \%$ & 9 & $4.5 \%$ \\
\hline 10. & $\begin{array}{l}\text { Correct technique for drying hands after surgical hand } \\
\text { washing is rotatory motion from finger to elbow using sterile towel. }\end{array}$ & 108 & $53.7 \%$ & 93 & $46.3 \%$ & 0 & $0 \%$ \\
\hline
\end{tabular}

Table 2 reveals that a question was asked about environmental cross infection where $88.56 \%$ participants had knowledge whereas $7.96 \%$ had no knowledge. In response to a question that, the single most important measure for preventing Hospital Acquired Infection is hand hygiene, $82.58 \%$ participants gave correct response saying yes while remaining $16.43 \%$ had no knowledge and gave incorrect response. Result also shows in response to a question that, immunization against Hepatitis $\mathrm{B}$ is a standard precaution, $73.6 \%$ participants gave correct response while $24.38 \%$ gave incorrect answer and $2 \%$ don't know. It was also found to a question that, Hospital acquired infections are the result of self-infection, cross-infection \&environmental infection, $71.1 \%$ participants gave correct response while $26.9 \%$ gave incorrect answer and $2 \%$ don't know. To another question that sterilization is a process of killing of microorganisms including spores, $62.18 \%$ partici- pants gave correct response while $35.82 \%$ gave incorrect answer and $2 \%$ don't know. Table 2 also shows in response to a question that, the most important factor involved in hand washing is friction, $73.13 \%$ participants gave correct response while $21.4 \%$ gave incorrect answer and $5.47 \%$ don't know. It was also found in result to a question that, hand washing is necessary after removing the gloves, $70.1 \%$ participants gave correct response while $26.4 \%$ gave incorrect answer and 3.5\% don't know. In response to another question that, standard precautions apply only to all body fluid, 59.2\% participants gave correct response while $36.3 \%$ gave incorrect answer and $4.5 \%$ don't know. The above table 2 founds to a question that Correct technique for drying hands after surgical hand washing is rotatory motion from finger to elbow using sterile towel, $53.7 \%$ participants gave correct response while $46.3 \%$ gave incorrect answer. 


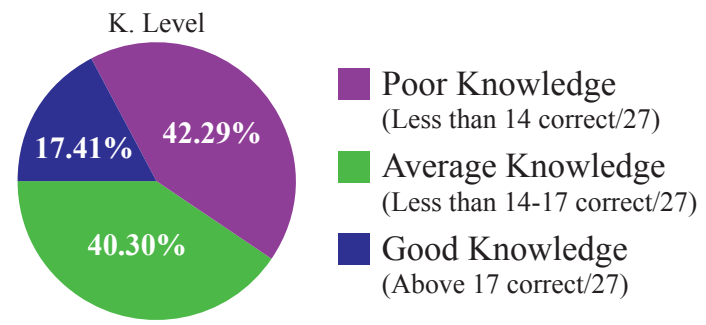

Figure 1 reveals that $42.29 \%$ of the participants were having poor knowledge who gave less than 14 correct answers out of 27 questions. $40.3 \%$ had average knowledge who gave 14-17 correct answers and only $17.41 \%$ had good knowledge and gave 18 or more correct answers out of 27 questions being asked.

Fig. (1). Overall Knowledge of Standard Precaution Among Nurses.

Table 3. Knowledge of Nurses Regarding Standard Precautions.

\begin{tabular}{|c|c|c|c|c|c|}
\hline \multirow[t]{2}{*}{ S. No. } & \multirow[t]{2}{*}{ Statement } & \multicolumn{2}{|c|}{ Correct } & \multicolumn{2}{|c|}{ Incorrect } \\
\hline & & $\mathbf{N}$ & $\%$ & $\mathbf{N}$ & $\%$ \\
\hline 1. & $\begin{array}{c}\text { Alcohol based hand rubs have good or excellent antimicrobial activity against all of } \\
\text { following except }\end{array}$ & 107 & $53.2 \%$ & 94 & $46.8 \%$ \\
\hline 2. & $\begin{array}{l}\text { Alcohol-based hand rubs are indicated for all of the following clinical situations } \\
\text { except }\end{array}$ & 98 & $48.8 \%$ & 103 & $51.2 \%$ \\
\hline 3. & $\begin{array}{l}\text { Which statement indicates best understanding of the correct protocol for blood \& } \\
\text { body fluid isolation }\end{array}$ & 131 & $65.2 \%$ & 70 & $34.8 \%$ \\
\hline 4. & $\begin{array}{c}\text { Which of the following is the 1st priority in preventing infections when providing } \\
\text { care for a client }\end{array}$ & 159 & $79.1 \%$ & 42 & $20.9 \%$ \\
\hline 5. & Normal skin flora usually consists of & 127 & $63.2 \%$ & 73 & $36.8 \%$ \\
\hline 6. & $\begin{array}{l}\text { The appropriate concentration of available chlorine to decontaminate spillage of } \\
\text { blood is }\end{array}$ & 135 & $67.2 \%$ & 66 & $32.8 \%$ \\
\hline 7. & Use contact precautions for the following infections except & 107 & $53.2 \%$ & 94 & $46.8 \%$ \\
\hline 8. & Which is the proper way of disposal of used needles and sharp materials & 100 & $49.8 \%$ & 101 & $50.2 \%$ \\
\hline 9. & Most of the blood borne infections acquired in the work place is the result of & 102 & $50.7 \%$ & 99 & $49.3 \%$ \\
\hline 10. & $\begin{array}{l}\text { This of the statement about surgical attire is correct Sterile surgical gloves should } \\
\text { be considered contaminated }\end{array}$ & 103 & $51.2 \%$ & 98 & $48.8 \%$ \\
\hline 11. & Which of the following are considered as medical waste & 100 & $49.8 \%$ & 101 & $50.2 \%$ \\
\hline 12. & For droplet precautions wear surgical mask within & 87 & $43.3 \%$ & 114 & $56.7 \%$ \\
\hline
\end{tabular}

Table 3 shows the findings of nurses knowledge regarding standard precaution among nurses. It was found that $53 \%$ study participants knew that alcohol based rub are good antimicrobial except for bacterial spores. About $48.8 \%$ gave correct response that Alcohol rubs are used always but not when there is presence of visible solid waste on hands. $79 \%$ participants answered correctly that Hand Hygiene is the 1st priority in preventing infections when providing care for a clien. $63.2 \%$ answered correctly that Normal skin flora usually consists of Staph-epidermidis. $67.2 \%$ of the study participants responded correctly that appropriate concentration of available chlorine to decontaminate spillage of blood is $1 \%$. Pertussis does not required contact precaution answered correctly by $53.2 \%$ of the study participants. Dispose it in puncture resistant containers is the proper way of disposal of used needles and sharp materials correctly answered by $49.8 \%$. Correctly replied that preventable accidents with sharps cause most of the blood borne infections acquired. $51 \%$ of the study participants replied correctly that Sterile surgical gloves should be considered contaminated if gloved hands drop below the level of waist. $49.8 \%$ replied that used bandages are considered as medical waste. $43.3 \%$ of the participants replied correctly that in droplet precautions wear surgical mask within 6 feet of patients.

Table 4. Difference of Knowledge Regarding Standard Precaution among Nurses Private versus public Hospitals.

\begin{tabular}{|c|c|c|c|c|c|c|}
\hline Standard Measures & T Test Value & DF & $\begin{array}{l}\text { Mean Knowledge } \\
\text { Public/Private }\end{array}$ & Sig. (2-tailed) & $\begin{array}{r}95 \% \mathrm{Co} \\
\text { Interval of }\end{array}$ & $\begin{array}{l}\text { ice } \\
\text { rence }\end{array}$ \\
\hline \multirow[b]{2}{*}{ Values found } & \multirow[b]{2}{*}{2.416} & \multirow[b]{2}{*}{199} & \multirow[b]{2}{*}{$14.66 / 13.45$} & \multirow[b]{2}{*}{0.017} & Lower & Upper \\
\hline & & & & & 0.221 & 2.184 \\
\hline
\end{tabular}

Table 4 reveals that the mean knowledge score of public hospital was $14.66+3.167$, which is greater than private hospital knowledge score $13.45+3.863$. It also shows that there is significant difference between the public versus private hospitals because the $\mathrm{p}$ value is 0.017 which is less than 0.05 . 


\section{DISCUSSION}

It was found that the results of current study reveals that $42.29 \%$ of the participants were having poor knowledge who gave less than 14 correct answers out of 27 questions. $40.3 \%$ had average knowledge who gave 14-17 correct answers and only $17.41 \%$ had good knowledge and gave 18 or more correct answers out of 27 questions being asked.

According to a previous study the knowledge level of nurses and nursing students was very low regarding standard precaution at clinical practices [12].

According to previous research study it was found that only $24 \%$ had the good knowledge regarding the standard precautions which was even lower than this current study [20].

Results of another study conducted among health professional showed that $80 \%$ of the research participants had good knowledge about standard precautions. It was also suggested that to improve knowledge and adherence towards standard precaution, there must be proper education and training [4].

The finding of this current study reveals that the mean knowledge score of Female was $14.14+3.393$, which is less than Male knowledge score $16.13+3.499$. It also shows that there is significant difference between the female versus males because the $\mathrm{p}$ value is 0.003 which is less than 0.05 .

The results of another survey found that knowledge level was not up to standard and $43 \%$ nurses had poor level of knowledge about hospital infection. The knowledge level was found significantly different between males and females $(\mathrm{r}=$ $00.8 \mathrm{p}=0.02)[15]$.

Findings of another previous study show that Female nurses had better knowledge of standard precaution than males' nurses. It was also found in a previous study that 10 years or more experienced nurses also had better knowledge of standard precautions $(p<0.05)$. Compliance of using sterile gloves, effective use of needles and sharps was higher than the knowledge of these procedures recorded $(p<0.05)$ [17].

\section{LIMITATIONS}

- Less sample size 200 due to which, the findings cannot be generalized.

- Time was too short, to see any prospective events or detailed associations of awareness and practices.

- Convenient sampling technique was used which may have some biasness.

\section{CONCLUSION}

Standard Precautions are vital measures that play an important role for prevention of infection in hospital setting. This study concluded that knowledge of standard precaution among nurses is significantly low. As compare between public hospital and private hospital, knowledge is significantly high in nurses working at public sector. This study calls for a need to build capacity of Nurses on standard precaution; it may with continue medical education or other educational programs. When there is low level of knowledge it will affect practice and compliance.

\section{CONFLICT OF INTEREST}

Declared none.

\section{ACKNOWLEDGEMENTS}

I am highly thankful to Allah for giving me the strength and knowledge to carry out this research work. Without Allah's blessings and providence it would not be possible to complete this research project successfully. After that I am grateful to my parents and family members who gave me enough courage and support to complete this work

I am highly thankful to Madam Naseem Roman and Sir Afsar Ali who guided me at every step of this research project. I also want to convey my thanks to both National College of Nursing as well as UOL School of Nursing administration for their support and coordination and complete cooperation.

\section{REFERENCES}

[1] Kuhar DT, Henderson DK, Struble KA, et al. Updated US Public Health Service guidelines for the management of occupational exposures to human immunodeficiency virus and recommendations for postexposure prophylaxis. Infect Control Hosp Epidemiol 2013; 34(9): 875-92.

DOI: $10.1086 / 672271$

[2] Dhar S, Marchaim D, Tansek R, et al. Contact precautions more is not necessarily better. Infect Control Hosp Epidemiol 2014; 35(3): 213-9. DOI: 10.1086/675294

[3] Ortega CD. Knowledge, attitude and practices on universal precautions of staff nurses and midwives in the delivery room. Asian J Health 2015; 5(1).

[4] Okhiai O, Nwaopara AO, Omoregbe FI, et al. A study on knowledge, attitude and practice of standard precautions among theatre personnel in Irrua Specialist Teaching Hospital, Irrua, Edo State. Int J Basic Appl Innov Res 2014; 3(4): 147-53.

[5] Ndu AC, Arinze-Onyia SU. Standard precaution knowledge and adherence: Do doctors differ from medical laboratory scientists? Malawi Med J 2017; 29(4): 294-300.

DOI: $10.4314 / \mathrm{mmj} . v 29 \mathrm{i} 4.3$

[6] Labrague LJ, Rosales RA, Tizon MM. Knowledge and compliance of standard precautions among student nurses. Int J Adv Nurs Stud 2012; 1(2): 84-97.

DOI: $10.14419 /$ ijans.v1i2.132 
[7] Wang H, Fennie K, He G, Burgess J, Williams AB. A training programme for prevention of occupational exposure to bloodborne pathogens: Impact on knowledge, behaviour and incidence of needle stick injuries among student nurses in Changsha, People's Republic of China. J Adv Nurs 2003; 41(2): 187-94. DOI: 10.1046/j.1365-2648.2003.02519.x

[8] La-Rotta EI, Garcia CS, Barbosa F, dos Santos AF, Vieira GM, Carneiro M. Evaluation of the level of knowledge and compliance with standart precautions and the safety standard (NR-32) amongst physicians from a public university hospital, Brazil. Rev Bras Epidemiol 2013; 6: 786-97.

DOI: $10.1590 / \mathrm{S} 1415-790 X 2013000300021$

[9] Punia S, Nair S, Shetty RS. Health care workers and standard precautions: perceptions and determinants of compliance in the emergency and trauma triage of a tertiary care hospital in south India. Int Sch Res Notices 2014; 2014: 685072.

DOI: $10.1155 / 2014 / 685072$

[10] Valim MD, Pinto PA, Marziale MHP. Questionnaire on standard precaution knowledge: Validation study for brazilian nurses use. Texto Contexto-Enfermagem 2017; 26(3): [Epub 21-Set-2017].

[11] Bolaji-Osagie SO, Adeyemo FO, Onasoga OA. The knowledge and practice of universal precautions amongst midwives in Central Hospital, Benin City. J Public Health Epidemiol 2015; 7(11): 331-6. DOI: 10.5897/JPHE2015.0732

[12] Darawad MW, Al-Hussami M. Jordanian nursing students' knowledge of, attitudes towards, and compliance with infection control precautions. Nurs Educ Today 2013; 33(6): 580-3. DOI: 10.1016/j.nedt.2012.06.009

[13] Hinkin J, Cutter J. How do university education and clinical experience influence pre-registration nursing students' infection control practice? A descriptive, cross sectional survey. Nurs Educ Today 2014; 34(2): 196-201.

DOI: 10.1016/j.nedt.2013.09.005
[14] Ghanbari MK, Shamsi M, Farazi AA, et al. The survey of knowledge, self-efficacy and practice of nurses in standard precautions to prevent nosocomial infections in hospitals of Arak university of medical sciences in 2013. J Arak Uni Med Sci 2013; 16(7): 45-54.

[15] Sarani H, Balouchi A, Masinaeinezhad N, Ebrahimitabas E. Knowledge, attitude and practice of nurses about standard precautions for hospital-acquired infection in teaching hospitals affiliated to Zabol University of Medical Sciences (2014). Glob J Health Sci 2015; 8(3): 193-8.

DOI: $10.5539 /$ gjhs.v8n3p193

[16] Ogoina D, Pondei K, Adetunji B, Chima G, Isichei C, Gidado $\mathrm{S}$. Knowledge, attitude and practice of standard precautions of infection control by hospital workers in two tertiary hospitals in Nigeria. J Infect Prev 2015; 16(1): 16-22.

DOI: $10.1177 / 1757177414558957$

[17] Abdulraheem I, Amodu MO, Saka MJ, Bolarinwa OA, Uthman MMB. Knowledge, awareness and compliance with standard precautions among health workers in North Eastern Nigeria. J Commun Med Health Educ 2012; 2(3): 1-5.

[18] Chaudhuri S, Baidya OP, Singh TG. Knowledge and attitude of universal precaution among nursing staff in a tertiary hospital of Manipur. Int J Commun Med Public Health 2017; 3(2): 451-4.

[19] Franklin OE. The knowledge and practice of standard precautions among health care workers in public secondary health facilities in Abuja, Nigeria. Dissertation. South Africa: University of South Africa 2009.

[20] Kolude O, Omokhodion F, Owoaje E. Universal precaution: Knowledge, compliance and perceived risk of infection among doctors at a University Teaching Hospital. In: International Conference of Aids 2004; Abstract no. MoPed 3676. 